\title{
Prevention of recurrent acute cystitis by methenamine hippurate: double blind controlled crossover long term study
}

\author{
S CRONBERG，C-O WELIN， L HENRIKSSON，S HELLSTEN，K M-S PERSSON, \\ P STENBERG
}

\begin{abstract}
In a randomised, double blind, long term, crossover study $1 \mathrm{~g}$ twice daily of methenamine hippurate was compared with placebo for its preventive effect on recurrent attacks of acute cystitis. Methenamine hippurate and placebo were interchanged every six months for two years. During one of the years patients took $250 \mathrm{ml}$ extra fluid every morning and evening. Out of 21 enrolled patients, 14 completed the first year and 13 both years of treatment, which permitted the evaluation of 27 patient years. There were 52 episodes of acute cystitis caused by reinfection: 41 occurred during placebo treatment and only 11 during the methenamine hippurate regimen $(p<0 \cdot 01)$. Extra fluid intake did not reduce the incidence of acute cystitis, nor did it reduce the effect of methenamine hippurate.
\end{abstract}

Methenamine hippurate is an effective prophylactic agent against recurrent acute cystitis and has the advantage of not inducing cross resistance to conventional antibiotics.

\section{Introduction}

Methenamine was introduced for treating urinary tract infections a century ago. ${ }^{1}$ Despite reports of a preventive effect on recurrent acute cystitis ${ }^{23}$ its efficacy has remained questionable. ${ }^{4}$ Increased

\footnotetext{
Departments of Infectious Diseases, Gynaecology, Urology, Bacteriology, and Pharmacy, University of Lund, Malmö General Hospital, S-214 01 Malmö, Sweden

S CRONBERG, MD, assistant professor of infectious diseases

C-O WELIN, MD, consultant in infectious diseases

L HENRIKSSON, MD, assistant professor of gynaecology

S HELLSTEN, MD, assistant professor of urology

K M-S PERSSON, MD, consultant in bacteriology

P STENBERG, PHD, director of hospital pharmacy

Correspondence to: Dr S Cronberg, Department of Infectious Diseases, General Hospital, S-214 01 Malmö, Sweden.
}

fluid intake alone may reduce the incidence of cystitis, but it may also dilute the preventive effect of methenamine hippurate. ${ }^{5}$ In a double blind crossover study we evaluated the effectiveness of methenamine hippurate, with and without extra fluid intake, in preventing acute recurrent cystitis.

\section{Trial and results}

Twenty one women aged 40-80 with recurrent acute cystitis but otherwise healthy and free from renal disease were included in the study. Each patient gave informed consent to the study (which was also approved by the university's research ethics committee) and was randomised to receive either methenamine hippurate (Hiprex Riker Laboratories) $1 \mathrm{~g}$ twice daily or identical placebo for six months in a double blind manner. The drugs were interchanged every six months for two years. During one of these the patients were prescribed $250 \mathrm{ml}$ extra fluid every morning and evening. Eleven patients started with methenamine hippurate and six of them also took extra fluid. Ten patients started with placebo, five of them together with extra fluid. Urine cultures were performed with standard methods and antibiotic sensitivity assessed by disc diffusion. A urinary tract infection was defined as $\geqslant 10^{8}$ colony forming units/l urine. The patients attended hospital every two months or whenever they had symptoms of cystitis. Patients with urinary tract infections received appropriate antibiotics for a week. Recurrence of infection with the same organism with identical antibiotic sensitivities within a month was considered to be a relapse. A reinfection was characterised by the appearance of a new bacteriological species, or of the earlier species with a different sensitivity, or of the earlier species after a symptom free interval of over a month.

Only new infections and not relapses were included for analysis. Differences in the frequency of cystitis for the individual patients during treatment were analysed by Wilcoxon's matched pairs rank sum test.

Of the 21 patients entering the study, 14 completed the first year and 13 both years. Two patients withdrew soon after the start complaining of urgency. One of them was taking the active drug, the other placebo, but both had been given extra fluid. Otherwise no side effects occurred and the patients who withdrew from the trial did so through lack of motivation. In 27 patient years there were 52 attacks of acute cystitis due to reinfection, 11 in patients taking methenamine hippurate and 41 in patients taking placebo (table). Methenamine hippurate thus reduced the incidence of acute cystitis by $73 \%$. One patient had seven attacks while taking placebo but none while taking the active drug.

Ten patients had fewer attacks while taking methenamine hippurate than 
placebo. The reverse occurred in one patient, who had a single episode with methenamine hippurate but was otherwise free of infection. The Wilcoxon matched pairs rank sum test gave a significant result $(\mathbf{p}<0.01)$.

Out of five relapses, four occurred while patients were taking placebo. Most infections were due to Escherichia coli (table). There was no difference between patients taking extra fluid and those with a normal fluid intake (28 versus 24 attacks), and extra fluid did not reduce the efficacy of methenamine hippurate (six versus five attacks). There were no signs of a carryover effect, and 23 episodes occurred in the first year versus 29 in the second year.

Organisms causing acute cystitis during study

\begin{tabular}{|c|c|c|c|c|c|}
\hline $\begin{array}{c}\text { Drug } \\
\text { treatment }\end{array}$ & $\begin{array}{c}\text { Total No of } \\
\text { cases of cystitis }\end{array}$ & $\begin{array}{l}\text { No of cases during } \\
\text { extra fluid intake }\end{array}$ & & \multicolumn{2}{|c|}{$\begin{array}{l}\text { No of cases during } \\
\text { ordinary fluid intake }\end{array}$} \\
\hline Placebo & 41 & 22 & & 19 & \\
\hline & & $\begin{array}{l}\text { E coli } \\
\text { Klebsiella } \\
\text { Proteus mirabilis } \\
\text { unknown }\end{array}$ & $\begin{array}{l}15 \\
3 \\
3 \\
1)\end{array}$ & $\begin{array}{l}\text { E coli } \\
\text { Klebsiella } \\
\text { Proteus mirabilis } \\
\text { Enterobacter } \\
\text { Enterococci }\end{array}$ & $\begin{array}{l}11, \\
3, \\
1, \\
1, \\
3)\end{array}$ \\
\hline Methenamine hippurate & 11 & $\begin{array}{l}\text { E coli } \\
\text { Proteus mirabilis } \\
\text { Streptococcus group B } \\
\text { unknown }\end{array}$ & $\begin{array}{l}3, \\
1, \\
1 \\
1)\end{array}$ & $\left(E_{\text {coli }}{ }^{5}\right.$ & 5) \\
\hline
\end{tabular}

\section{Discussion}

We found $2 \cdot 1$ infections per patient/year with placebo but only 0.8 with methenamine hippurate $(\mathrm{p}<0.01)$. These figures are better than those reported after administration of $2 \mathrm{~g}$ methenamine mandelate together with $2 \mathrm{~g}$ ascorbic acid, indicating that ascorbic acid is unnecessary.

Because methenamine hippurate is well tolerated, is effective, and fails to produce cross resistance to conventional antibiotics it seems to be a suitable prophylactic agent against recurrent acute cystitis in women.

We thank Mr Ulf Parkhede and Mrs Margareta Gunolf, Riker Laboratories, for their help and support.

\section{References}

1 Nicolaier A. Über die therapeutische Verwendung des Urotropin (Hexamethylentetramin). Deutsch Med Wochenschr 1895;21:541-3.

2 Harding GKM, Ronald AR. A controlled study of antimicrobial prophylaxis of recurrent urinary infection in women. $N$ Engl $\mathcal{Y}$ Med 1974;291:597-601.

3 Petersen S. Long-term prophylaxis with methenamine hippurate in girls with recurrent urinary ract infections. Acta Paediatr Scand 1978;67:597-9.

Cain B B Mus A PM Lack of effect of mo7:597-9. chronic urinary infection. Antimicrob Agents Chemother 1977;12:625-9.

5 Katul MJ, Frank IN. Antibacterial activity of methenamine hippurate. $\mathcal{F}$ Urol 1970;104:320-4.

\title{
Atrial natriuretic peptide concentrations in pre-eclampsia
}

\author{
JØRN KVIST THOMSEN, TOMMY LYAGER STORM, GORM THAMSBORG, \\ MICHAEL DE NULLY, BIRGIT BØDKER, SVEN SKOUBY
}

\begin{abstract}
The concentration of plasma immunoreactive atrial natriuretic peptide is positively associated with right atrial and pulmonary capillary wedge pressure, suggesting that blood volume and hence atrial pressure govern its release. Expansion of plasma volume is a central physiological adjustment in normal pregnancy. Conversely, pregnancies complicated by pre-eclampsia are associated with a reduction in plasma volume and central venous pressure. A study was therefore undertaken to test the hypothesis that plasma atrial natriuretic peptide concentrations are low in pre-eclampsia owing to deficient secretion. Concentrations of the peptide were measured by a specific radioimmunoassay.

The mean plasma immunoreactive atrial natriuretic peptide concentration in healthy pregnant women $(n=22$; third trimester) was higher (56 (1 SD 29) ng/l) than in 25 young, non-pregnant controls ( $37(19) \mathrm{ng} / \mathrm{l})$. Concentrations in patients suffering from mild pre-eclampsia $(n=9)$ were higher $(127(60) \mathrm{ng} / \mathrm{l})$ than in
\end{abstract}

Department of Gynaecology and Obstetrics, KAS Herlev, Denmark JøRN KVIST THOMSEN, MD, registrar

MICHAEL DE NULLY, MD, registrar

BIRGIT BØDKER, MD, registrar

SVEN SKOUBY, MD, senior registrar

Department of Medicine, Sundby Hospital, Copenhagen, Denmark TOMMY LYAGER STORM, MD, research fellow GORM THAMSBORG, $M D$, registrar

Correspondence and requests for reprints to: Dr Tommy Lyager Storm, Department of Internal Medicine, Sundby Hospital, 2300 Copenhagen S, Denmark. normal pregnant women, and in patients with severe preeclampsia $(n=6)$ concentrations were higher still $(392(225) \mathrm{ng} / \mathrm{l})$.

Despite failure of plasma volume expansion and low central venous and pulmonary capillary wedge pressures in pre-eclampsia this condition is associated with greatly increased plasma concentrations of plasma immunoreactive atrial natriuretic peptide, which increase still further with the severity of the disease. These findings are clear evidence that atrial pressure may not be the principal determinant of the release of the natriuretic peptide in pre-eclampsia.

\section{Introduction}

The atria of the heart have long been thought to have a role in blood volume control. It has recently been shown that atrial natriuretic peptide is released into the blood by stretching of the atria after expansion of the blood volume. Atrial natriuretic peptide acts on the kidney to promote excretion of salt and water, thus decreasing the extracellular fluid volume and maintaining homoeostasis. ${ }^{1}$ Besides the direct natriuretic and diuretic effects atrial natriuretic peptide inhibits vasoconstriction induced by angiotensin II and noradrenaline and reduces secretion of both renin and aldosterone. ${ }^{2}$

The physiological adjustments in normal pregnancy include an increase in plasma volume, renal plasma flow, and glomerular filtration rate and a decrease in total peripheral resistance. In addition, normal pregnant women are extremely resistant to the pressor effect of infused angiotensin II. ${ }^{3}$ By contrast, in preeclampsia there is a failure of plasma volume expansion ${ }^{4}$ accompanied by salt retention. Renal plasma flow and glomerular filtration rate are less than in normal pregnancy and patients show an increased pressor responsiveness to angiotensin $\mathrm{II}^{s}$ and an increase in 